\title{
The Business of State Capture in the Western Balkans
}

\section{An Introduction}

\author{
Valery Perry
}

Democratization Policy Council, Bosnia and Herzegovina valeryperry@yahoo.com

\section{Soeren Keil}

Canterbury Christ Church University, United Kingdom keil.soeren@gmail.com

\section{Introduction}

It is well known that the countries of the Western Balkans have been undergoing multiple, simultaneous and interconnected transitions - political, economic and post-war - for a generation. However, while the links between the political and the post-violent conflict transitions have been studied extensively over this period, the connections between the political and the economic, or among all three of these processes, have been less explored, leaving a gap in the understanding of the post-war political economy and its consequences. This special issue seeks to explore the region from this perspective, to begin to untangle the interplay of ineffective and incomplete political and economic reform on liberal democratic consolidation.

In addition, there has been insufficient appreciation of the role that the non-violent yet significant frozen conflicts have had on political and social development, particularly (but not only) in Bosnia and Herzegovina ( $\mathrm{BiH}$, or Bosnia), Kosovo and Macedonia. The contributions in this special issue all begin to explore this as well. Post-Dayton $\mathrm{BiH}$ and post-Ohrid Macedonia offer

* The papers included in this special issue were originally presented in two panels at the Association for the Study of Nationalities Annual Conference in 2016. The editors would like to thank all contributors to the two panels, the chairs and discussants for their valuable input, the external reviewer for their comments and advice, and Anna Krasteva and Marco Puleri for their support. 
examples of unresolved structural, political and identity debates, less a result of essentialist grassroots urges than of dynamics that have been reified and manipulated by party structures dependent on identity politics for survival. ${ }^{1}$ Post - independence Kosovo's development is affected by unresolved status issues with Serbia, which has provided nearly a decade of tension during which both sides have managed to keep the conflict alive and resonant in the media and public space, while at the same time ensuring a lasting excuse for lagging reforms and a useful populist mobilizing tool. ${ }^{2}$

The articles in this special issue each explore the dynamics of these transitions, focusing on the emergence of various forms of state capture that have developed over time. While the end of the Cold War - for a short-time at least seemed to herald the "victory" of liberal democratic ideas accompanied by free market capitalism, it has become abundantly clear that there are many different forms of transitional political and economic models that can in fact fill the post-Communist vacuum. The contributions in this volume demonstrate that in the Western Balkans one can discern a spectrum of state capture where dynamics are in constant flux, and it is possible for a country's position on the spectrum to change over time.

The absence of a robust literature on state capture in the region provides ample room for both examining individual case studies, and, inter alia, theorizing broader trends and common characteristics. However it poses conceptual challenges as well, as no single model exists which can itself satisfactorily frame the various countries in the region. But there are commonalities in method and outcome, and state capture is not an accidental outcome, or an unintended phenomenon; it can represent a sophisticated and intentional system. One of the aims of this special issue is to study the characteristics of these systems, each of which exhibits certain functional rules (formal or informal), evolves in response to flaws and weaknesses, and builds on shared historical and developmental paths - paths often linked to political and social transition and efforts to overcome the results of the violent conflicts of the 1990s. Each of the authors provides a different perspective on the issue in terms of both theory and case study reality, and in doing so begin to sketch out the practical institutional outcome of what Zakaria first termed "illiberal democracy" 20 years ago. The spectrum of state capture represents this unanticipated postCold War chimera on a continent on which many assumed the enlightenment values debate had been settled.

1 See Jelena Džankić's contribution in this special issue.

2 See Soeren Keil's contribution in this special issue. 


\section{Framing the Transition to State Capture}

The articles that follow sketch out key political and economic factors, but some overarching background is useful. Economic changes had begun in Yugoslavia before its violent political disintegration, as the country's financial crisis, hastened by the beginning of the end of the Cold War, led to initial changes in the business/economic environment such as the so-called Markovic reforms (Woodward 1995). ${ }^{3}$ In 1988, the Company Law was adopted, allowing sociallyowned/state-owned companies to reorganize, merge, and to transfer social capital from one enterprise to another, thereby becoming mixed companies, holding both social and private capital. The 1989 Social Capital Circulation and Management Law, and subsequent amendments in 1990, were intended to hasten the process by introducing further market innovations, including the ability to issue shares in a company to employees. These and other reforms led to the bankruptcy of approximately 1200 socially owned enterprises (Medjad 2004). As privatization was more aggressively introduced, different models were used in the different Yugoslav republics; Slovenia and Macedonia used a restitution approach; while $\mathrm{BiH}$, Croatia and Serbia would later adopt a voucher method for early rounds, later turning to foreign investment (Ibid. 311$).{ }^{4}$ At the start, privatization occurred mainly with small and medium enterprises (SMEs), with little to no change in the larger socially-owned enterprises, meaning that many of the biggest and most lucrative assets remained in "government" hands during and after the wars.

As political leadership changed hands, and as "communists" were quickly replaced with "nationalists," there was a scramble to seize and hold assets as a part of national consolidation efforts - in times of both war and peace. This process was not inclusive, transparent or fair - it was crony capitalism thinly masquerading as an embrace of free market principles in the service of nation-building and war. The period also saw renationalization when it was convenient to shift so-called "socially owned" business to pure state control. For example:

[In] Croatia, some 110 enterprises (mainly in infrastructure) were immediately transformed into state-owned firms run by government-appointed managers and were not subject to privatization (corresponding to around $40 \%$ of the value of all enterprises in social ownership). Some firms have

3 Ante Markovic was President of the Federal Executive Council of the Socialist Federal Republic of Yugoslavia, i.e. the head of government.

4 For more on the Kosovo experience, see www.kta-kosovo.org. 
also been nationalized in the guise of 'protecting national interests', such as the main oil company, which has the greatest assets and is the largest employer in Croatia, and the largest foreign trade company. In firms scheduled for privatization, workers did have the right to buy their enterprise assets on privileged conditions, but since real wages diminished sharply owing to high inflation, assets were in many cases seized by managers and directors.

DALLAGO AND UVASLIĆ, 1998: 83

In Serbia,

substantial parts of the economy have been renationalized, although there was no automatic transfer of unsold shares to state-owned institutions. By mid-1993 around $37 \%$ of the capital of social sector enterprises (mainly natural monopolies) had become state property. In privatizing social sector enterprises, as in Croatia, managers and workers were given the possibility to buy enterprise shares on privileged terms. However, since hyperinflation allowed the subscription and repayment of shares at ridiculously low real prices, the Democratic Party reacted by stressing the unfair outcome of privatization.

DALLAGO AND UVASLIĆ, 1998: 84

The ruling elites and their clients were the near sole benefactors of this free market shock; they enjoyed a first-mover advantage at a time when society as a whole was struggling through the social chaos, upheaval and displacement caused by violence and war. There were no checks and balances, no independent institutions, no counter-balances to resist or protest this asset seizure.

A generation later, in spite of "progress" as the wars have ended, as the countries have joined the Council of Europe and other bodies as states in their own right, and as the countries of the former Yugoslavia have embarked on their individual European Union (EU) integration paths at various speeds, the region still seems to suffer from a shortage of both good governance and effective economic policy and development. Instead, for at least a decade it has been clear that the region is in many ways becoming less democratic, and more authoritarian in both political and economic outlook. ${ }^{5}$ This is the unfortunate

5 In May 2015 Kurt Bassuener noted, "I fear that the way the EU is approaching the Western Balkans is much the same as the way it is approaching the Southern Mediterranean-North Africa and the Middle East. That is, stability is paramount and trumps progress and democracy. 
but logical outcome of economic "wild West" liberalization in the absence of genuine political or institutional liberalization.

While these outcomes have gained new relevance in terms of concerns of the rising economic dislocation and dissatisfaction at the core of growing populist movements in even seemingly functional democracies, the potential for such turmoil has been predicted for over two decades. Barber (1995) early on recognized the consequences of such an economic strategy in a world undergoing globalization while individual states struggled to build new identities in this new and very unbalanced world. While his argument is global in nature, his analysis of the experience of these reforms in Eastern Europe and the Soviet Union is particularly acute. '[The] new transitional democracies have been talked by foreign advisors or bullied by international banks into thinking that laissez-faire capitalist economics is a self-sufficient social system. Predictably, the results have been catastrophic.... What Alexander Solzhenitsyn calls "savage capitalism"' - a system 'fraught with unproductive, savage and repulsive forms of behaviour, the plunder of the nation's wealth' - has turned the new Russia into a place where 'the brazen use of social advantage and the inordinate power of money (the very problems the collapse of communism was supposed to cure!) are today worse than ever' (Barber, 2001, 238-239).

Magyar's description of the impact of rapid-fire privatization in Hungary is similar in tone and content, as he notes, "... the opportunities for corruption were legion as the former state socialist countries rapidly privatized huge swaths of the economy in the 1990s without a regulatory regime in place to oversee and regularize the privatization" (Magyar, 2016, xix). George Soros, no stranger to global financial maneuvering, has referred to unquestioned capitalist orthodoxy and the premise that markets are perfect and perfectly selfregulating as "market fundamentalism" (2008). Glenny (2008) has examined the impact of economic globalization and market development in terms of transnational organized crime, a trend that has always demonstrated the entrepreneurial faculties of its participants, but which with the massive influx of cash and assets in the 199os privatization wave (and financial deregulation that eased money laundering) suddenly enjoyed access to more money and political clout than previously possible. The analyses by Barber, Magyar, Soros

As a result, the union risks aligning itself with increasingly illiberal and authoritarian regimes and figures by default, and mistaking their power for stability." "Judy Asks: Is the Eu Sleeping on the Western Balkans?" Carnegie Europe. 13 May 2015. Available at http://carnegieeurope .eu/strategiceurope/?fa=60o69. See also for a more recent assessment: BiEPAG 2017 . 
and Glenny would all ring true to the average citizen of each of the countries under consideration in this collection, who has witnessed these processes in real-time and first-hand.

This special issue goes to the heart of this matter, examining the real-world result of gravely flawed transitions through a combination of thematic comparative analyses and case studies. As will be demonstrated across the contributions, in order to understand state capture in the former Yugoslav states, it is important to go beyond the classical definition of state capture as efforts by individuals, groups, or firms, both in the public and private sectors, to shape the laws, policies, regulations, decrees, and other government policies for their own advantage and gain (Hellman, Jones and Kaufmann 2000). Instead, as several authors point out throughout this special issue, state capture in the Western Balkans focuses on government elites and their grip on power. They use political, social and economic means to extend their own influence and ensure their dominant position in these transitional political systems. While corruption is an important dimension in this discussion, it is by far not sufficient to theorize and evaluate developments in the countries of the former Yugoslavia, as both John Hulsey and Joseph Coelho point out in their contributions. Indeed, in order to understand state capture in the countries under examination different perspectives have to be taken into account. First, as discussed above, economic liberalization and political change occurred at a time of regime change and violence in many of these countries. This opened doors for political and economic elites to take a dominant position in both realms, thereby ensuring that economic and political "liberalization" would be framed in a way that would suit their interests and not threaten their position. Montenegro is probably the most obvious example of this development, as pointed in out in the papers by Soeren Keil and Jelena Džankić. Second, the period after the violent conflicts, in which democratization and state-building by international actors dominated numerous countries, paved the way for certain elites to not only clinch their existing dominant position, but also to extend their power by manipulating external actors and the processes of state-building and democratization in their favor. This has already been discussed in detail in previous work we completed on Bosnia and Herzegovina (Keil and Perry 2015), and it is discussed by Joseph Coelho in his case study of Kosovo. Third, existing ethnic divisions and the continued contestation of numerous countries and their political systems have further allowed actors to take control of political, social and economic institutions, as Jelena Džankić details.

Looking at these wider issues raises of course the question of what can be done to counterbalance state capture and new authoritarian tendencies in the 
region. Some authors in this special issue focus on the role of the $\mathrm{EU}$ and its conditionality. Others point out that only deep-rooted reforms that lead to the establishment of functional countries in which the rule of law is respected will help in overcoming existing problems. However, as John Hulsey reminds us in his paper, once state capture has become system-endemic, it is very hard to get rid of. Recent developments in Macedonia, where a semi-authoritarian government has been toppled in elections and through street protests, demonstrate that change might be possible. It remains, however, to be seen if the new government in Skopje will be able to avoid the mistakes of its predecessors, particularly when it comes to tackling corruption, ensuring more transparency in government policy and strengthening the rule of law.

\section{Contributions to this Special Issue}

John Hulsey's paper provides some theoretical framing for this special issue. Looking at state capture in Bosnia and Herzegovina in comparative perspective, he points out that the conceptualization of state capture is very difficult, and that many of the indicators often used might be problematic. Instead, he argues, we should focus on the current structure of the political system and the role of political elites in it. How did they come to power? Which resources can they mobilize, both to get into power, and to stay in power? How closely are economic, societal and political systems linked and indeed mixed? Discussing the case of $\mathrm{BiH}$, he demonstrates how after the war parties representing the three main ethnic groups in the country have been able to dominate economic and political systems in the territory of "their ethnic group," while at the same time working together at the central level to ensure that the joint resources are shared equally between the main parties. The lack of party competition across ethnic lines, and power-sharing institutions that support extreme and exclusive political positions, as well as a lack of the rule of law have further contributed to the current situation in Bosnia and Herzegovina. Hulsey provides a wider discussion of what constitutes state capture and how it could (and should) be tackled.

David Kanin provides a provocative contribution, questioning the assumption that non-patronage based systems are achievable, reasonable or even desirable in the Balkans. He argues that it is Quixotic to assume that external incentives can change trust networks that he argues have existed in the region for generations. In this reading of past and recent history, so-called patronage networks are simply an informal yet, in Kanin's view, effective way of organizing 
society. The "in groups" and "out groups" that may emerge from such a system are in effect no different than those one may find in parliamentary systems that result in certain parties enjoying power while others remain mired in opposition. He suggests that to question the legitimacy of these systems is neo-colonial and even patronizing, revealing an ignorance of informal social practices. Kanin aims to challenge the conventional wisdom among "western" powers promoting so-called traditional norms of liberal democracy and good governance. When taken in the context of global events in 2017 some key ideas deserve consideration: is it in fact the case that nepotism is the norm, and meritocratic bureaucracies are the exception? Are bribes just another measure of how much someone values something, akin to a market price? And, in the context of EU enlargement, should the EU expect that new members adjust to Brussels-articulated norms, or be prepared to bend to these different practices? If the latter is the case, then what is the future of enlargement?

Soeren Keil's article provides a comparative view of state capture trends and practices in four countries: Kosovo, Macedonia, Montenegro and Serbia. After providing a framework for democratization and authoritarian backsliding, he considers four constitutive parts that have heretofore provided a backbone for liberal governance - the separation of powers, the role of bureaucracies and independent agencies, the strength of civil society and an independent media and the tone and content of policy making - to explore how the cases under consideration have to varying extents whittled away the "checks and balances" elements required to ensure an effective counter-weight against authoritarian instincts held by any one party/coalition or individual leader. He also crucially links the process of state capture - regardless of the extent or success of the phenomenon - to illiberal and authoritarian trends in these countries. At a time when even members of the EU - most notably Hungary and Poland - are moving away from the liberal values that have provided the foundation for the European project, these trends in potential future members is troubling, leading to questions about not only their future integration into the $\mathrm{EU}$, but also the net gain that such countries could contribute to a union that seems less and less rooted in a shard sense of norms and values.

Jelena Džankić analyzes three countries - Bosnia and Herzegovina, Macedonia and Montenegro - according to two dimensions (one internal, and one external) that have enabled and facilitated state capture. The internal factor reflects ongoing unresolved identity issues that have been effectively exploited and manipulated by ethnic entrepreneurs to facilitate continued divisions that enable the maintenance of unaccountable and often illiberal systems. The external factor is related to the continued external contestation of these sovereign states that unsettles both their domestic and foreign policies and 
posture. Two of these cases can point to internationally brokered agreements as at least a partial source of this instability. In BiH the Dayton Agreement created a structure that put a premium on ethno-national control in the electoral system and virtually all levels of governance, via the territorial administrative division in the country and the legitimation of the notion of three constituent peoples within these sub-state units. In Macedonia, the Ohrid Agreement created a different dynamic than that seen in $\mathrm{BiH}$, but one that is still rife with tensions, trading accountable governance and representation for fragile political party interest-based coalitions. Montenegro, compared to these other cases, enjoys a certain amount of normalcy. However, the attempted coup in 2016 and the continued tensions with Serbia and Russia provide outside destabilizing influences. Džankić argues that these "structural anomalies" facilitate elite capture, and weaken processes of democratic consolidation that could otherwise serve as checks and balances. She focuses on two processes that have unfolded in these post-communist environments - the development of public administration systems that have served as an opportunity to stock one's "own" within the pool, according to ethno-national and/or party lines; and privatization processes which uniformly unfolded in a nontransparent and often closed manner, building an elite capable of entrenching and reproducing.

Joseph Coelho's detailed case study of Kosovo echoes a number of these themes, while adding the role and impact of the significant international presence in Kosovo. He finds that the intentional administration played both a direct and indirect role in if not creating the conditions for state capture, then in facilitating the conditions necessary for state capture. Methods used have included the misuse or improper channeling of foreign aid to existing or emerging clients, privatization under questionable procedures and the legitimization of unaccountable politicians unwilling to denounce conflict or interest and overt corruption by international partners - primarily the EU and the US - desperate for stability. He explains this by applying the stability paradigm to Kosovo, explaining how the west's prioritization of stability over potentially destabilizing application of the rule of law and accountable politics have created a minimally accountable and generally corrupt system in Europe's newest country. While Kosovo continues to fail to adequately address the concerns of its Serbs (a tension abetted by the role of Belgrade in seeking some sort of de facto Serb entity within Kosovo), its lack of $\mathrm{BiH}$ - or Macedonia-like ethnonational problems demonstrate that the drivers of the conditions for state capture depend just as much on structural deficiencies, the lack of checks and balances and a depletion of norms as on the divide and conquer temptations viewed in some of its neighbors. 


\section{Conclusion}

Together, the articles in this issue will contribute to needed debate. Global discussions on economic inequality, the ineffectiveness of governance, and the unsuitability of political party options have resulted in a variety of developments, ranging from the emotionally driven citizen choices in support of Brexit and the election of Donald J. Trump as us president, to the emergence of Emmanuel Macron as an outsider candidate interested in reshaping France's domestic systems while also supporting the EU. While the famous saying "We live in interesting times" might be more relevant than many would want it to be, it is nevertheless important to think about what these developments mean. For example, the discussion about state capture in the former Yugoslavia could be put in a wider framework, challenging the liberal internationalist paradigm that has dominated international relations for years, and which saw American hegemony, democracy promotion and support for economic liberalization at its core. Has support for free market capitalism in the absence of a structure supporting the rule of law led to economic liberalization without political liberalization? Furthermore, it could be argued that state capture in the region is enabled by the re-emergence of the Eastern Question, with Russia supporting semi-authoritarian leaders in Macedonia, Serbia and Bosnia and Herzegovina's Republika Srpska, and Turkey, the Gulf states and China playing a more prominent role in the region as well. Finally, as the EU is overcoming the Brexit shock and still dealing with the refugee crisis, the future of enlargement, and indeed of the $\mathrm{EU}$ as a political project, remains in question as more inward-focused right-leaning parties are elected to office on anti-status quo platforms.

Yet, while the picture that the authors in this special issue paint might seem bleak, there are counterbalancing processes at work as well. Citizen protests occurred in all former Yugoslav countries. In Macedonia, they have recently demonstrated that they can influence government policy and indeed overcome the false stability of the new semi-authoritarian regimes; however the future is far from certain. Civil society faces unexpected challenges, as an alternative illiberal version of it is emerging in the region with support from the right (and the governments itself) and an agenda seemingly opposed to the liberal enlightenment values espoused by the EU. Whether this trend will in the long term meaningfully strengthen civil society and citizen agency in the broad sense, or represent one more element of state capture, remains to be seen. Likewise, the emergence of new political parties and new political elites such as Saša Janković in Serbia, who focus on economic liberalism and 
democratic governance, can also be observed in some countries, though the impact to date remains limited.

Kanin's thought-provoking article perhaps forces anyone interested in these issues to return to first principles. Is it in fact possible that western liberal approaches to political and civic life are simply neither relevant to nor desired by the vast majority of people living in this region? Is the status quo in fact more "legitimate" than one might think, explaining the continued electoral success of the same people and the same parties year after year? And if this is the case, then how can one reconcile this with future region-wide EU membership, and the (presumed) commitments to good governance, the rule of law and anticorruption initiatives expected of its members?

Even if agreeing with Kanin's argument, and accepting that non-patronage based societies are a global exception rather than the norm, unless a captured state and its patronage system is so pervasive and all-encompassing that the vast majority are satisfactorily included within it, there will always be an outside group, either vying to displace the present "insiders" within the same system, or perhaps seeking a system that would not require an out-group at all. Such an "outgroup" can either be co-opted through the expansion of patronage networks, marginalized as opposition or challenged as an undesirable social option (perhaps through labelling such groups as Soros-funded foreign agents), draping the status quo in concepts of patriotic tradition. Such systems may or may not be sustainable in the long term.

A few options can provide some food for thought for future work on this topic in the region.

First, if the EU enlargement processes to date have illustrated anything, it is that Brussels enjoys precious few tools to sanction, encourage or otherwise respond to unpalatable state actions once they become a member. Hungary and Poland are often first noted, but other countries (Cyprus, Greece) are also straining the Eu's institutions, values and norms; the response by Brussels to such developments among its members remains uncertain. This does demonstrate however that it is important to ensure that reforms made during the accession process are meaningful and deep, and are not only adopted but effectively implemented, with genuinely independent structures and systems able to ensure lasting enforcement. This will not be easy; critics will suggest that strict conditionality amounts to changing the terms of accession, and that it is better to have these countries inside the tent as soon as possible (Chandler 2010; Jovic 2015). However, allowing new weak states to become members will not only not help citizens in those countries, but will contribute to enlargement-fatigue and disillusionment in the Union as a whole (Keil and 
Arkan 2014), as citizens and their representatives wonder why they are suddenly bound with countries that have failed to meaningfully reform.

The fact that this will be difficult leads directly to a second recommendation. As Hulsey explains, there are substantial obstacles to changing systems that have begun to internalize aspects of state capture into formal and informal governance structures. Parties and politicians will inherently reject reforms if they feel that they would be "losing" according to the current rules of the game. Opposition voices, often facing an uphill battle in the best of circumstances, have failed to effectively make their case, making it still easier for the status quo to calcify. The EU and other external actors would do well to more aggressively speak directly to the citizens of prospective members states, and to more assiduously make an effort to cultivate positive domestic forces supportive of more open and accountable governance. In tandem, supporters of open, liberal systems should be encouraged to look at the systems and structures in their societies to determine what makes them accountable, and what additional incentives could be introduced to increase the accountability link between citizens and officials elected or appointed to serve.

This leads to a third recommendation, related to the values of the EU and its members, and more broadly, the values of the liberal, democratic West. Has the West lost the values debate, not only in the region but more broadly? This is a discussion that will not only continue but likely accelerate as increasing and deep dissatisfaction seems to sweep the consolidated democracies and transitional countries alike. The socio-economic pain stemming from the 2008 financial crisis reflected not only structural weaknesses in the global financial infrastructure, but also growing social dissatisfaction with government responses. Rising economic inequality and overall social insecurity have made other social fears (immigration, heterogeneous societies, the "other") more poignant. The UK vote for Brexit was more a reflection of these concerns (and their exploitation) than the merits of EU membership, and the election of Donald Trump in the us, and his presidency to date, send similarly contradictory signals, reflecting an inchoate populism grounded in the sense that the economic system that seemed to bring great post-World War II growth is no longer delivering for the average citizen. This inward looking populism naturally has an impact on states' foreign policies as well, and, in an environment in which there is a security vacuum in terms of global leadership, provides ample opportunity for different actors with different agendas to assert themselves in hybrid ways in the Balkans - the most notable such actor in this instance being Russia. (Bassuener and Perry 2017). 
It remains to be seen how countries in the region - or the world in general will face these social challenges. Will more authoritarian models such as in China be viewed as preferable? Will citizens be willing to trade certain basic values of openness and transparency in exchange for infrastructure, real (or promised) rapid annual growth, better living conditions, etc.? Or will be there be a tipping a point when people decide that in addition to economic benefit they want political freedoms, independent institutions and accountable governments? While the countries in the Balkans have experienced their tumultuous political and economic flux over the past generation, resulting in various manifestations of state capture that reflect specific institutional and social weaknesses, the challenges and temptations are not unique to the region, and in fact can be expected to be increasingly evident globally as the post, postCold War world continues to evolve and emerge.

\section{References}

Barber, Benjamin R. (2001) Jihad vs. McWorld: Terrorism's Challenge to Democracy. Ballantine Books.

BiEPAG (2017): The Crisis of Democracy in the Western Balkans. Authoritarianism and eu Stabilitocracy. Policy Brief. Available at: http://www.suedosteuropa.uni-graz .at/sites/default/files/article_attach/BIEPAG\%20-\%20The\%2oCrisis\%20of\%20 Democracy\%2oin\%2othe\%2oWestern\%2oBalkans.\%2oAuthoritarianism\%2o and\%20EU\%20Stabilitocracy\%2oprint.pdf [last accessed 14 June 2017].

Chandler, David (2010) "The EU and Southeaster Europe: the Rise of post-Liberal Governance." Third World Quarterly. Vol. 31, pp. 69-85.

Dallago, Bruno and Milica Uvalić (1998): The Distributive Consequences of Nationalism: The Case of Former Yugoslavia in: Europe-Asia Studies. 50/1, pp. 71-90.

Glenny, Misha (2008) McMafia: A Journey through the Global Criminal Underworld. Vintage.

Hellman, J.S, G. Jones and D. Kaufmann. 2000. Seize the State, Seize the Day: State Capture, Corruption and Influence in Transition Washington, DC: World Bank.

Jovic, Dejan (2015) "Instead of Enlargement, 'Restern Balkans' in Consolidation." European Western Balkans. 29July 2015. Available at https://europeanwesternbalkans .com/2015/07/29/instead-of-enlargement-restern-balkans-in-consolidation/.

Keil, Soeren and Arkan, Zeynep. (2014) 'Conclusion' in: Keil, Soeren and Arkan, Zeynep (eds.): The EU and Statebuilding: European Foreign Policy in the Western Balkans, Basingstoke: Routledge, 233-239. 
Keil, Soeren and Perry, Valery (eds.) (2015): State-Building and Democratization in Bosnia and Herzegovina. Abingdon and London: Ashgate.

Magyar, Balint (2016) Post-Communist Mafia State. Central European University Press. 2016.

Medjad, Karim (2004): The Fate of the Yugoslav Model: A Case Against Legal Conformity in: The American Journal of Comparative Law. 52/1.

Woodward, Susan (1995): Balkan Tragedy. Washington DC: Brookings.

Zakaria, Fareed. "The Rise of Illiberal Democracy." Foreign Affairs. November/ December 1997. 